\title{
UM ESTUDO DOS LEITMOTIVS DE CEM ANOS DE SOLIDÃO
}

\section{A STUDY OF THE LEITMOTIVS OF CEM ANOS DE SOLIDÃO}

\author{
Altamir Botoso ${ }^{1}$
}

Recebido em: 03 jul. 2019.

Aceito em: 29 dez. 2019;

DOI 10.26512/aguaviva.v5i2.25688

RESUMO: Cem anos de solidão, de Gabriel García Márquez, é considerado como um dos grandes romances da literatura latino-americana pela crítica especializada. Instigados por essa premissa, objetivamos analisar os leitmotivs ou motivos estruturadores dessa obra, que se centram em quatro tópicos: o mito da estirpe, o uso da categoria do realismo mágico, o tempo cíclico e a história da América Latina. Em síntese, esses motivos atestam a plurissignificação do romance analisado e a capacidade de invenção de seu autor.

Palavras-chave: Leitmotiv. Gabriel García Márquez. Cem anos de solidão. Literatura colombiana.

ABSTRACT: Cem anos de solidão, by Gabriel García Márquez, is considered one of the greatest novels of Latin American Literature by specializes critics. Instigated by this premise we aim to analyse the leitmotivs or structuring motifs of this book, which focus on four topics: the myth of the lineage, the use of the magical realism category, the cyclical time and the history of Latin America. In short, these motifs attest to the plurissignification of the novel and the capacity of invention of his author.

Keywords: Leitmotiv. Gabriel García Márquez. Cem anos de solidão. Colombian literature.

\section{INTRODUÇÃO}

De acordo com estudiosos e críticos literários, o romance Cem anos de solidão (1967), do escritor colombiano Gabriel García Márquez (1927-2014), sem sombra de dúvida, é uma das obras mais importantes da ficção latino-americana do século XX. Já foi objeto de análise em incontáveis artigos, dissertações e teses. Trata-se de um texto que, a cada leitura, abre-se para novas descobertas e significados insuspeitados. E é sempre um desafio muito instigante

\footnotetext{
${ }^{1}$ Licenciatura Plena em Letras: Português e Italiano pela Universidade Estadual Paulista Júlio de Mesquita Filho (1995), graduação em Licenciatura Plena em Letras: Português e Espanhol pela Universidade Estadual Paulista Júlio de Mesquita Filho (1989), graduação em Licenciatura Plena em Letras: Português e Francês pela Universidade Estadual Paulista Júlio de Mesquita Filho (1993), mestrado em Letras [Assis] pela Universidade Estadual Paulista Júlio de Mesquita Filho (1998) e doutorado em Letras [Assis] pela Universidade Estadual Paulista Júlio de Mesquita Filho (2004).E-mail: abotoso@uol.com.br
} 
mergulhar em suas páginas, procurando evidenciar e sistematizar alguns aspectos de sua construção.

Nesse sentido, nosso objetivo é analisar alguns leitmotivs no livro mencionado tais como: o tema da estirpe, o uso da categoria do realismo mágico, a temporalidade cíclica e as referências à história latino-americana. O estudioso alemão Wolfgang Kayser (apud MOISÉS, 2004, p. 258) afirma que leitmotivs são "os motivos centrais que se repetem numa obra, ou na totalidade da obra, de um poeta" ou prosador.

Acreditamos que os quatro motivos condutores que selecionamos possibilitarão uma análise verticalizada e aprofundada da narrativa de García Márquez, uma vez que eles são recorrentes ao longo da história da saga da família Buendía e mantém conexões que serão explicitadas no decorrer desse ensaio, que se encontra dividido em duas partes: na primeira, fornecemos resumidamente os dados do enredo e, na segunda, efetuamos a análise proposta.

\section{A saga da família Buendía}

Devido ao grande número de personagens que atuam no romance, julgamos pertinente reproduzir a árvore genealógica dos componentes da família Buendía, suas uniões e seus herdeiros:

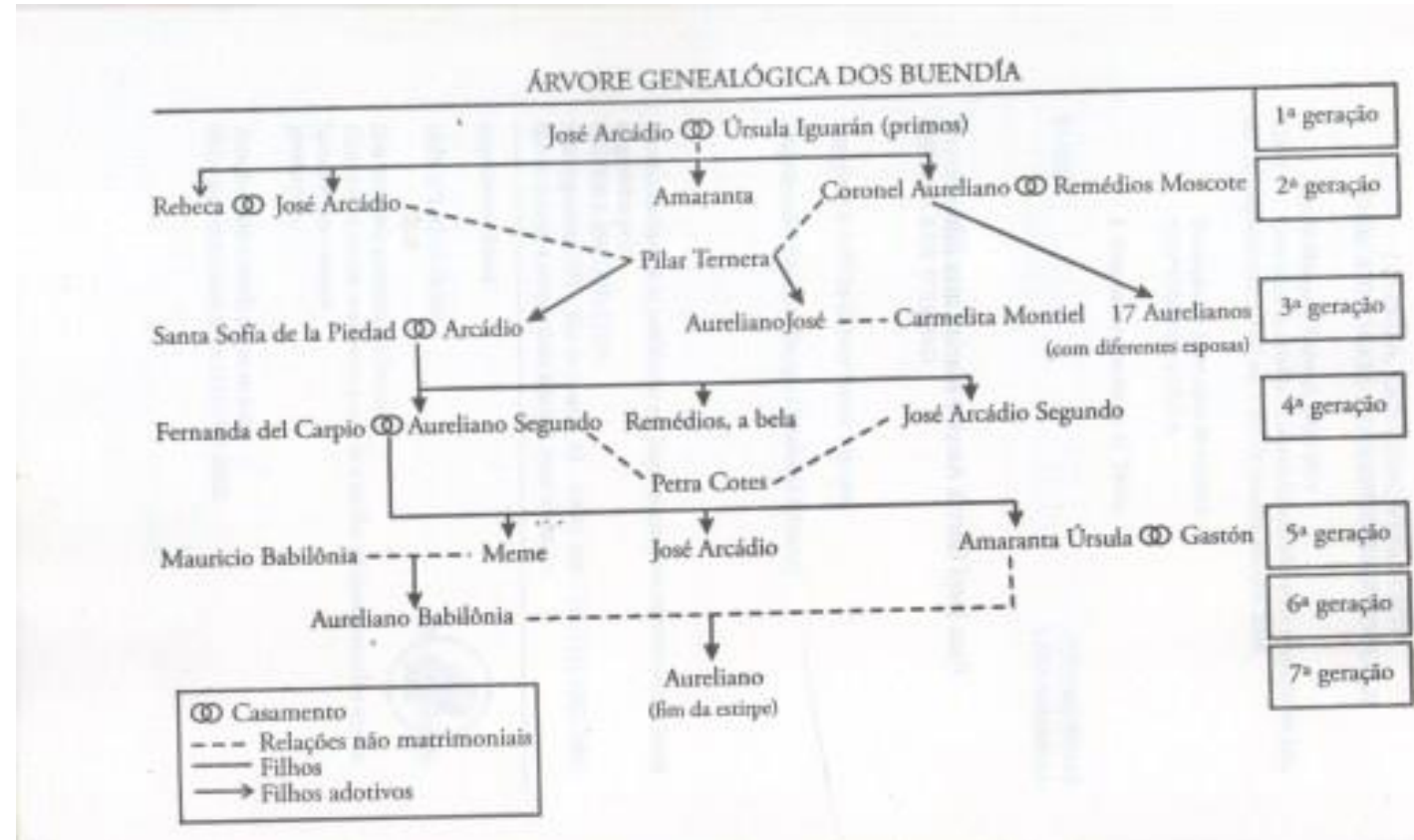

(GARCÍA MÁRQUEZ, 2014, p. 42) 
José Arcádio Buendía e Úrsula Iguarán são primos e se casam. Anteriormente, uma tia de Úrsula, casada com um tio de José Arcádio, teve um filho que passou toda a vida com calças largas e frouxas e morreu de uma hemorragia, porque nasceu e cresceu "com uma cauda cartilaginosa em forma de saca-rolhas e com uma escova de pelos na ponta. Um rabo de porco que nunca deixou ser visto por nenhuma mulher, e que lhe custou a vida quando um açougueiro amigo lhe fez o favor de cortá-lo com uma machadinha de retalhar" (GARCÍA MÁRQUEZ, 2014, p. 25).

Temerosa de que esse fato se repetisse, Úrsula procurou conservar sua castidade vestindo sempre "umas calças compridas e rudimentares [...] reforçadas com um sistema de correias entrecruzadas, que se fechava na frente com uma grossa fivela de ferro" (GARCÍA MÁRQUEZ, 2014, p. 26). Essa roupa impedia todo intento de consumar o casamento. Prudencio Aguilar, numa briga de galos na qual é perdedor, ofende a José Arcádio, dizendo: "Vamos ver se afinal esse galo resolve o caso da sua mulher" (GARCÍA MÁRQUEZ, 2014, p. 36), e este mata-o com uma lança.

O morto começa a aparecer no pátio da casa dos Buendía, obrigando-os a abandonar o povoado onde viviam. Assim, em companhia de alguns amigos, depois de uma longa peregrinação, acampam junto a um rio e, naquela noite, “José Arcádio Buendía sonhou que bem ali erguia-se uma cidade ruidosa com casas de paredes de espelho. Perguntou que cidade era aquela, e lhe responderam com um nome que nunca havia ouvido, que não tinha significado algum, mas que teve no sonho uma ressonância sobrenatural: Macondo" (GARCÍA MÁRQUEZ, 2014, p. 66). Ali fundam uma aldeia.

O casamento resulta no nascimento de três filhos: José Arcádio, Aureliano e Amaranta. O chefe da família, José Arcádio Buendía, na velhice, enlouquece e é amarrado a um castanheiro até a sua morte. Seus três filhos são normais e não confirmam a premonição. Eles são diferentes e individualizados: José Arcádio é voluntarioso, mas sem imaginação; Aureliano tem uma rara intuição alquímica; Amaranta apresenta grande capacidade sexual, mas como teme o ato, nunca chega a consumá-lo. José Arcádio apaixona-se por Pilar Ternera, com quem tem um filho, Arcádio. Seu espírito boêmio, aventureiro e travesso leva-o pelo mundo, saindo de Macondo com uns ciganos.

Quando retornou, apaixonou-se por Rebeca, que fora trazida por estranhos e entregue à família Buendía, para que a criasse. Ela carregava "um saco de lona que fazia um eterno ruído de cloc cloc cloc, onde trazia os ossos de seus pais" (GARCÍA MÁRQUEZ, 2014, p. 44). Casou-se com José Arcádio e ambos viveram numa completa solidão, dedicados somente ao 
amor, e não deixaram descendência. Num episódio não explicado e que permanece como um mistério não resolvido dentro da história narrada, Rebeca atira em José Arcádio e o mata. Ela morre sozinha no velho casarão do casal.

Aureliano também manteve relações com Pilar Ternera e conceberam um filho, Aureliano José, que morre jovem, atingido por uma "bala de fuzil que lhe entrou pelas costas e lhe despedaçou o peito" (GARCÍA MÁRQUEZ, 2014, p. 151).

Em Macondo, chegou Apolinar Moscote e sua família. Aureliano apaixona-se por sua filha menor, Remedios, que não havia chegado à puberdade. Quando isso acontece, a família prepara-a para que seja capaz de assumir as responsabilidades de uma boa esposa e ambos se casam. Entretanto, ela morre pouco tempo depois, "com um par de gêmeos atravessado no ventre" (GARCÍA MÁRQUEZ, 2014, p. 127). Aureliano torna-se um revolucionário, lançandose em guerras civis.

Arcádio, filho de José Arcádio e Pilar Ternera, atormentado pelo amor incestuoso que sente pela tia - Amaranta - casa-se com Santa Sofía de la Piedad. O casal tem uma filha, Remedios, a Bela, e gêmeos, José Arcádio Segundo e Aureliano Segundo.

Amaranta foi cortejada pelo general Gerineldo Márquez. Anteriormente, havia disputado com Rebeca o amor de Pietro Crespi, com quem esta estava comprometida, e Amaranta mostrava-se interessada por ele também. Quando Rebeca apaixonou-se e se casou com José Arcádio, Amaranta perdeu seu interesse por Pietro Crespi, que se suicidou. A beleza e a candura de Remedios, a Bela, causou a morte de um comandante e de um cavalheiro elegante, pois ela "enfeitiçava" os homens com sua beleza, até que em uma das cenas mais bonitas do romance, ela eleva-se em direção ao céu e ninguém mais a vê.

Os gêmeos José Arcádio Segundo e Aureliano Segundo compartilham os amores de Petra Cotes. Esses amores não deixam descendência. Aureliano Segundo casa-se com Fernanda del Carpio e têm três filhos: José Arcádio, que foi estudar em Roma para tornar-se Papa e regressou cheio de manias e um pouco afeminado; Meme ou Renata, que se criou como uma garota moderna e teve um relacionamento trágico com Mauricio Babilônia, terminando encarcerada em um convento; Amaranta Úrsula, que foi enviada a Bruxelas para estudar e retornou casada com Gastón.

Do convento no qual Meme ingressou, já grávida, enviaram um bebê para os Buendía, que foi batizado com o nome de Aureliano. Ele, por ser um filho bastardo, era ocultado por Fernanda. Cresceu esquivo e solitário. Inventou-se a história de que ele havia sido encontrado em um cesto e, dessa forma, Aureliano e Amaranta sabiam que não eram irmãos, embora ela 
imaginasse que pudesse haver algum parentesco, devido ao relacionamento de seu pai com Petra Cotes.

No seu regresso de Bruxelas, Amaranta Úrsula desperta um amor avassalador em Aureliano e ambos entregam-se a esse amor. Gastón volta à Europa. Desse amor, cujo incesto se suspeita, nasce o último dos Buendía, Aureliano, mas com rabo de porco, cumprindo-se assim a premonição. Também se decifram os pergaminhos de Melquíades, um cigano que, desde as primeiras páginas do romance, aparece rodeado de certo mistério e que foi amigo de José Arcádio Buendía e viveu e morreu como se fosse um membro de sua família.

Quando decifra os pergaminhos, Aureliano, filho de Meme, lê: "O primeiro da estirpe está amarrado a uma árvore e o último está sendo comido pelas formigas. [...] Era a história da família, escrita por Melquíades, inclusive nos detalhes mais triviais, com cem anos de antecipação" (GARCÍA MÁRQUEZ, 2014, p. 392-393).

No final da narrativa, Amaranta Úrsula tem uma hemorragia e morre. O recém-nascido é arrastado e comido pelas formigas e Aureliano também morre com a destruição de Macondo.

\section{Realismo mágico, tempo cíclico e destruição de Macondo}

O romance está dividido em vinte capítulos que não têm numeração e nem outro tipo de ordenação, nos quais os episódios da formação de Macondo e da família Buendía vão justapondo-se. A esse respeito, Josefina Ludmer (1989, p. 7) tece o seguinte comentário:

Cem anos de solidão está construído sobre uma árvore genealógica e sobre o mito de Édipo. Esses dois eixos constituem o fundamento da narrativa, mas também o fundamento da atividade de leitura: ler uma árvore genealógica, não só em sua extensão mas também em sua intenção e em sua espessura, é ler uma série de formas com um tipo especial de organização; ler o mito de Édipo é ler o mito das relações de parentesco, outra versão da árvore genealógica. As relações de parentesco, a árvore genealógica, constituirão para nós "a realidade"; o mito de Édipo conformará a ideologia dessa realidade, o modo de vive-la imaginariamente: entre esses dois níveis assentam as formas de nossa leitura. [...]

Assim como Édipo, que precisa descobrir o sentido das premonições do oráculo, os descendentes da família Buendía empenham-se em decifrar os manuscritos de Melquíades. Ao final de suas trajetórias, tanto Édipo como Aureliano (filho de Meme e Mauricio Babilônia) descobrem uma verdade terrível, que cometeram incesto e que a verdade que procuravam ocultava-se nas suas árvores genealógicas e eles foram levados a essa situação sem nada poder fazer para evitá-la. 
A história da família Buendía é narrada à maneira bíblica, isto é, perderam-se as verdadeiras dimensões de tempo e espaço. Um homem tanto pode viver setenta anos como duzentos, segundo este critério. Assim aparecem os feitos da família Buendía: no marco do impreciso, que é também o marco do magnífico. Nesse mundo pode ocorrer qualquer coisa: uma mulher subir aos céus, uma criança nascer com rabo de porco, outra mulher saber com exatidão a hora de sua morte, um homem reencarnar ao longo dos tempos.

Os nascimentos e as mortes dos personagens da família Buendía, e dos homens e das mulheres que giram ao seu redor, marcam os acontecimentos que permitem compreender o desenvolvimento da história. Apesar da abundância de dados e do labiríntico modo no qual prolífera a narração, há indícios de ordem que nos ajudam a desentranhar o ciclo vital de Macondo e dos Buendía.

Assim, essa estrutura regida por mortes e nascimentos está integrada por quatro sequências principais:

1. O espaço geográfico e o tempo dos fundadores, essencialmente mítico.

2. O mundo e o tempo "histórico", formado pelo período de guerras civis nas quais toma parte o Coronel Aureliano Buendía.

3. O período cíclico, com o envelhecimento e morte dos primeiros personagens (Úrsula, José Arcádio Buendía, seus filhos), e a entrada de Macondo num mundo mais amplo, relacionado com o exterior (a companhia bananeira).

4. O final, morte e destruição de Macondo e dos últimos representantes da família Buendía (Aureliano, Amaranta, seu filho - que nasce com o estigma dos Buendía, o rabo de porco).

O primeiro período está marcado pela viagem de José Arcádio em busca do mar. A origem da peregrinação deve-se ao episódio no qual José Arcádio mata Prudencio Aguilar, que passa a persegui-lo como fantasma, até que José Arcadio e Úrsula decidem partir. As aparições de Prudencio Aguilar são o modelo da forma pela qual García Márquez integra ao texto realista os elementos que, tradicionalmente, consideram-se fantásticos:

Nem Prudêncio Aguilar foi embora, nem José Arcádio Buendía se atreveu a atirar a lança. Mas não tornou a dormir bem nunca mais. Era atormentado pela imensa desolação com que o morto o havia olhado da chuva, a profunda nostalgia com que recordava os vivos, a ansiedade com que revirava a casa buscando água para molhar sua atadura de cânhamo. "Deve estar sofrendo muito", dizia a Úrsula. "Dá para ver que está muito sozinho." Ela estava tão comovida que na outra vez em que viu o morto destampando as panelas no fogão entendeu o que ele buscava, e desde então pôs potes de água pela casa 
afora. Certa noite em que o encontrou lavando as feridas em seu próprio quarto, José Arcádio Buendía não conseguiu resistir.

- Está bem, Prudêncio - disse a ele. - Vamos embora deste lugar o mais longe que a gente conseguir, e não voltaremos mais. Agora vá tranquilo.

Foi assim que empreenderam a travessia da serra. Vários amigos de José Arcádio Buendía, jovens como ele, fascinados com a aventura, desmantelaram suas casas e arrastaram mulher e filhos rumo à terra que ninguém havia prometido. [...] (GARCÍA MÁRQUEZ, 2014, p. 65-65).

Nessa passagem, evidencia-se a origem da viagem de José Arcádio Buendía e Úrsula, que termina com a fundação de Macondo. Ela é também um exemplo básico do modo pelo qual García Márquez interpola o fantástico no plano mais estritamente realista. Com naturalidade, sem assombro, José Arcádio e Úrsula dialogam serenamente com o morto; este, por sua vez, carece de atitudes violentas, limita-se a aparecer diante dos Buendía. A partir daí, o mais estranho, o mais assombroso, o insólito, tudo transcorre tranquilamente, sem qualquer sobressalto dos personagens ou quaisquer questionamentos do leitor. Não há distorções nem efeitos violentos: a magia é a realidade cotidiana, assinalando a presença do realismo mágico no romance.

O romancista e ensaísta inglês David Lodge (2011, p. 122) esclarece, em breve texto, que

O realismo mágico - a interferência de acontecimentos fantásticos e impossíveis em uma narrativa realista - é um efeito associado em particular à ficção latino-americana contemporânea (encontram-se exemplos na obra do colombiano Gabriel García Márquez, por exemplo), mas ocorre também em romances vindos de outros continentes, como os de Günter Grass, Salman Rushdie e Milan Kundera. [...]

Como desafiar a lei da gravidade foi e continua sendo um grande sonho impossível, não é surpreendente que imagens de voo, levitação e queda livre ocorram com frequência nesse tipo de romance. No Cem anos de solidão de Márquez, um personagem ascende aos céus enquanto põe a roupa lavada para secar. No início de Os versos satânicos, de Salman Rushdie, os dois personagens principais caem agarrados um ao outro de um avião que explode, cantando, e aterrissam, sem nenhum arranhão, em uma praia inglesa coberta de neve. A heroína de Noites no circo de Angela Carter é uma trapezista chamada Fewers, que tem lindas plumas úteis não apenas para compor um figurino de palco: também são asas de verdade, que lhe permitem voar. Sexing the Cherry, de Jeanette Winterson, apresenta uma cidade flutuante, com habitantes flutuantes - [...]. E, [em] O livro do riso e do esquecimento, [de Milan Kundera], o autor afirma ter visto uma roda de dançarinos levantar voo e ir embora.

Complementando o pensamento de Lodge, o estudioso Friedl Kaal (1975, p. 3) pondera que o realismo mágico 
[...] Es un universo fantástico y extraordinario que se añade al mundo real sin atentar contra él ni destruir su coherencia. El mundo de los sueños, de los mitos, de las leyendas, de las supersticiones, son universos de magia que se añaden o forman parte del mundo real [...].

Dessa forma, o evento insólito, extraordinário insere-se na narrativa sem causar estranheza, sem que haja questionamentos ou dúvidas. Há vários episódios desse tipo em Cem anos de solidão e abaixo assinalamos oito passagens do romance que comprovam o emprego da categoria do realismo mágico na estruturação de seu enredo.

O primeiro fragmento, que transcrevemos, traz o encontro entre José Arcádio Buendía e Prudencio Aguilar falecido já há muitos anos. Além do inusitado da situação, outro fato chama a atenção: Prudencio Aguilar passa a estimar o seu algoz:

[...] Fatigou-se [José Arcádio Buendía] com a febre da insônia, que certa madrugada não conseguiu reconhecer o ancião de cabeça branca e gestos incertos que entrou no seu quarto. Era Prudencio Aguilar. Quando enfim o identificou, assombrado de que os mortos também envelhecessem, José Arcádio Buendía sentiu-se sacudido pela nostalgia. "Prudencio - exclamou -como é que você veio parar tão longe!" Depois de tantos anos de morte, era tão intensa a saudade dos vivos, tão urgente a necessidade de companhia, tão aterradora a proximidade da outra morte que existia dentro da morte, que Prudencio Aguilar havia terminado por gostar do pior de seus inimigos. Levava muito tempo procurando por ele. Perguntava aos mortos de Riohacha, aos mortos que chegavam do Vale de Upar, aos que chegavam do pantanal, e ninguém sabia dar com ele, porque Macondo era um povoado desconhecido para os mortos até que chegou Melquíades e apontou um pontinho negro nos coloridos mapas da morte. José Arcádio Buendía conversou com Prudencio Aguilar até o amanhecer. [...] (GARCÍA MÁRQUEZ, 2014, p. 118-119).

No próximo excerto, há a levitação do padre Nicanor Reyna, que se eleva doze centímetros do chão, para sensibilizar os moradores de Macondo a respeito da presença de Deus, para conseguir doações para construir uma igreja no povoado:

- Um momento - disse [Nicanor Reyna]. - Agora vamos presenciar a prova incontestável do infinito poder de Deus.

O garoto que havia ajudado na missa levou até ele uma xícara de chocolate espesso e fumegante que o padre tomou sem respirar. Em seguida limpou os lábios com um lenço que tirou da manga, estendeu os braços e fechou os olhos. E então o padre Nicanor elevou-se doze centímetros acima do nível do chão. Foi um recurso convincente. Andou vários dias pelas casas, de uma a outra, repetindo a prova da levitação pelo estímulo do chocolate, enquanto o coroinha reunia tanto dinheiro em um embornal que em menos de um mês começou a construção do templo. [...]. (GARCÍA MÁRQUEZ, 2014, p. 123124). 
A morte do patriarca de Macondo, José Arcádio Buendía, é acompanhada por uma chuva de flores amarelas, que dificultam até mesmo a passagem do cortejo fúnebre rumo ao cemitério:

Então entraram no quarto de José Arcádio Buendía, o sacudiram com todas as forças, gritaram em seu ouvido, puseram um espelho diante de suas narinas, mas não conseguiram despertá-lo. Pouco depois, quando o carpinteiro tomava as medidas para o ataúde, viram através da janela que estava caindo uma garoa de minúsculas flores amarelas. Caíram a noite inteira sobre o povoado numa tempestade silenciosa, e cobriram os telhados e tamparam as portas e sufocaram os animais que dormiam na intempérie. Tantas flores caíram do céu, que as ruas amanheceram atapetadas por uma colcha compacta, e foi preciso abri-las de novo com pás e ancinhos para que o cortejo pudesse passar. (GARCÍA MÁRQUEZ, 2014, p. 180).

O fragmento reproduzido abaixo trata da morte de José Arcádio (possivelmente cometido por sua esposa, Rebeca). O seu sangue passeia por ruas, jardins, alamedas, até chegar onde está sua mãe, para avisá-la do ocorrido e é impossível retirar o cheiro de pólvora do cadáver e este permanece no ar por muitos anos:

[...] Rebeca declarou depois que quando seu marido entrou no quarto ela se trancou no banheiro e não percebeu nada. Era uma versão difícil de acreditar, mas não havia outra mais verossímil, e ninguém conseguiu imaginar um motivo para que Rebeca assassinasse o homem que a havia feito feliz. Esse foi talvez o único mistério jamais esclarecido em Macondo. Assim que José Arcádio fechou a porta do quarto, o estampido de um tiro de pistola retumbou pela casa. Um fio de sangue escorreu por debaixo da porta, atravessou a sala, saiu à rua, continuou seu curso direto pelas calçadas desiguais, desceu escadarias e subiu parapeitos, passou ao largo da Rua dos Turcos, dobrou uma esquina à direita e outra à esquerda, girou em ângulo reto na frente da casa dos Buendía, passou por debaixo da porta fechada, atravessou a sala de visitas grudados no rodapé das paredes para não manchar as tapeçarias, continuou pela outra sala, driblou numa ampla curva a mesa da sala de jantar, avançou pela varanda das begônias e passou sem ser visto por baixo da cadeira de Amaranta, que dava uma aula de aritmética para Aureliano José, e se meteu pela despensa e apareceu na cozinha onde Ursula se preparava para quebrar trinta e seis ovos para o pão.

- Ave Maria Puríssima! - gritou Úrsula.

Seguiu o fio de sangue em sentido contrário, e à procura de sua origem atravessou a despensa, passou pela varanda das begônias onde Aureliano José cantava que três e três são seis e seis e três são nove, e atravessou a sala de jantar e a sala de visitas e continuou em linha reta pela rua, e depois dobrou à direita e em seguida à esquerda até a Rua dos Turcos, sem nem lembrar que usava o avental de cozinha e as pantufas caseiras, e saiu para a praça e entrou pela porta de uma casa onde não havia estado nunca, e empurrou a porta do quarto e quase se afogou no cheiro de pólvora queimada, e encontrou José Arcádio esticado de boca para baixo no chão sobre as polainas que acabava de tirar, e viu a fonte do fio de sangue que já havia deixado de fluir do seu ouvido direito. Não encontraram nenhum ferimento em seu corpo nem 
conseguiram localizar a arma. Também não foi possível tirar do cadáver o penetrante cheiro de pólvora. [...] (GARCÍA MÁRQUEZ, 2014, p. 171-172).

Numa das sequências mais belas de Cem anos de solidão, ocorre a ascensão de Remedios, a Bela, enquanto ela, Amaranta, Úrsula e Fernanda estão dobrando lençóis de linho no jardim, Remédios eleva-se em direção aos céus e desaparece do cenário do romance:

[...] Fernanda quis dobrar no jardim uns lençóis de linho, e pediu ajuda às mulheres da casa. Mal tinham começado quando Amaranta percebeu que Remedios, a Bela, estava quase transparente, com uma palidez intensa.

- Você está se sentindo mal? - perguntou.

Remedios, a Bela, que tinha agarrado o lençol pela outra ponta, fez um sorriso de lástima.

- Ao contrário - disse -, nunca me senti melhor.

Acabou de falar e Fernanda sentiu um delicado vento de luz que arrancou os lençóis de suas mãos e os estendeu em toda sua plenitude. Amaranta sentiu um tremor misterioso nas rendas de suas anáguas e tratou de se agarrar no lençol para não cair, no mesmo instante em que Remedios, a Bela, começava a se elevar. Úrsula, já quase cega, foi a única que teve a serenidade para identificar a natureza daquele vento irreparável, e deixou os lençóis à mercê da luz, vendo Remedios, a Bela, que dizia adeus com a mão, entre o deslumbrante bater de asas dos lençóis que subiam com ela, que abandonavam com ela o ar dos besouros e das dálias, e passavam com ela através do ar onde as quatro da tarde terminavam, e se perdia, com ela para sempre nos altos ares onde não podiam alcança-la nem os mais altos pássaros da memória. (GARCÍA MÁRQUEZ, 2014, p. 274).

No trecho que segue, o leitor depara-se com Mauricio Babilônia, que se apaixona por Meme, filho de Fernanda, que impede o relacionamento de ambos, pois eles pertencem a diferentes classes sociais. Todas as aparições desse personagem são precedidas por borboletas amarelas. O seu romance secreto com Meme é descoberto por Fernanda por causa delas, e tragicamente, ele acaba sendo alvejado e fica paralisado em cima de uma cama até a morte:

[...] Foi quando percebeu [Meme] de vez as borboletas amarelas que precediam as aparições de Mauricio Babilônia. Tinha visto aquelas borboletas antes, principalmente na oficina mecânica, e achou que estavam fascinadas pelo cheiro da pintura. Alguma vez as tinha visto revoando sobre sua cabeça na penumbra do cinema. Mas, quando Mauricio Babilônia começou a persegui-la como um fantasma que só ela identificava na multidão, compreendeu que as borboletas amarelas tinham alguma coisa a ver com ele. Mauricio Babilônia estava sempre na plateia dos concertos, no cinema, na missa maior dos domingos, e ela não precisava vê-lo para descobri-lo porque as borboletas amarelas indicavam onde ele estava. [...] (GARCÍA MÁRQUEZ, 2014, p. 323).

[...] Naquela noite, a guarda fulminou Mauricio Babilônia quando ele erguia as telhas para entrar no banheiro onde Meme esperava, nua e tremendo de amor entre os escorpiões e as borboletas, como tinha feito quase todas as 
noites dos últimos meses. Um projétil incrustado em sua coluna vertebral o reduziu à cama pelo resto da vida. Morreu velho na solidão, sem uma queixa, sem um protesto, sem uma única tentativa de traição, atormentado pelas recordações e pelas borboletas amarelas que não lhe concederam um só instante de paz, e repudiado publicamente como ladrão de galinhas. (GARCÍA MÁRQUEZ, 2014, p. 327).

Em outro trecho da narrativa do escritor colombiano, o narrador menciona a chuva que dura mais de quatro anos em Macondo:

Choveu durante quatro anos, onze meses e dois dias. Houve épocas de garoa em que todo mundo vestiu suas roupas de ver o bispo e armou uma cara de convalescente para celebrar a estiagem, mas logo todos se acostumaram a interpretar as pausas como anúncios de recrudescimento. O céu desabava numas tempestades de estropício, e o norte mandava uns furacões que destrambelhavam tetos e derrubavam paredes, e desenterravam pela raiz os últimos pés de plantações. [...] (GARCÍA MÁRQUEZ, 2014, p. 349).

Finalmente, o último excerto selecionado por nós traz o regresso de Melquíades, que, tal como Prudencio Aguilar, retorna do mundo dos mortos e vem visitar os vivos, em várias passagens do romance:

[...] Santa Sofía de la Piedad achava que Aureliano falava sozinho. Na verdade, conversava com Melquíades. [...]

Melquíades revelou a ele que suas oportunidades de voltar ao quarto estavam contadas. Mas ia embora tranquilo para as pradarias da morte definitiva, porque Aureliano teria tempo de aprender sânscrito nos anos que faltavam para que os pergaminhos completassem um século e pudessem ser decifrados. [...] (GARCÍA MÁRQUEZ, 2014, p. 390).

Nos episódios apontados, nota-se a habilidade de García Márquez para tornar verossímil inúmeros acontecimentos que se opõem à lógica do mundo racional que conhecemos. As levitações do Padre Nicanor e de Remedios assombram e, ao mesmo tempo, encantam os leitores, pelo inesperado e também pela beleza da descrição de Gabo. A imagem do sangue do filho que chega aos pés da mãe remete ao amor quase edipiano dos filhos pelas matronas hispânicas e é carregado de poeticidade, de uma imagem vívida e extremamente forte, encharcada de emoção e com uma tragicidade inigualável. E por fim, as aparições de Melquíades e Prudencio Aguilar, que acabam unindo o mundo dos vivos e dos mortos, estabelecendo entre ambos uma relação de complementaridade e eternidade.

Observando tais episódios que são recorrentes em Cem anos de solidão, é possível afirmar que 
[...] Una de las características más sobressalientes del [realismo mágico] consiste en presentar motivos de lo irracional integrados completamente en la vida cotidiana.

[...] en el texto mágicorrealista el conflito lógico entre lo natural y lo sobrenatural se suspende al aceptarse lo irracional como natural, [...] (RUIZ SERRANO, 2018, p. 176, 178).

Dessa forma, não são dadas outras informações ou explicações sobre os acontecimentos sobrenaturais, "sino que éstos se presentan como hechos naturales, suspendiendo así la extrañeza o incredulidad que en otro contexto podrían despertar" (RUIZ SERRANO, 2018, p. 179). Diferentemente do fantástico, no qual o evento ocorrido é parte de uma anormalidade, que deve ser investigada, no realismo mágico, aceita-se o evento insólito, estranho, em sua totalidade (OVIEDO PÉREZ DE TUDELA, 1999, p. 329), sem questionamentos ou qualquer dúvida por parte do leitor.

Na origem da estirpe dos Buendía há um crime (o de Prudencio Aguilar) e um problema de parentesco entre Úrsula e José Arcádio, que são primos. Por isso, Úrsula insiste em não consumar o casamento, já que pesa sobre eles o estigma de que seus filhos pudessem nascer com rabo de porco. Um crime e um estigma marcam para sempre os Buendía: o último descendente cumprirá a profecia. Efetivamente, o filho de Amaranta Úrsula e Aureliano nascerá com rabo de porco e não sobreviverá mais que umas poucas horas. Então, Aureliano compreende que a profecia de Melquíades, o cigano, está cumprindo-se sem remédio:

[...] Só então descobriu que Amaranta Úrsula não era sua irmã e sim sua tia, e que Francis Drake tinha assaltado Riohacha somente para que eles pudessem se buscar pelos labirintos mais intrincados do sangue, até engendrarem o animal mitológico que haveria de pôr fim à estirpe. [...] (GARCÍA MÁRQUEZ, 2014, p. 447).

As palavras de Melquíades, estampadas nos pergaminhos imemoriais da família, diziam: “O primeiro da estirpe está amarrado a uma árvore e o último está sendo comido pelas formigas" (GARCÍA MÁRQUEZ, 2014, p. 445, grifos do autor), apontando os dois extremos da narrativa - o princípio e o fim, com a morte do último Buendía e a destruição de Macondo.

O tema da estirpe é fundamental, uma vez que atravessa o romance desde o princípio até o final. A descendência dos Buendía organiza-se em períodos cíclicos, repetitivos, sucedendo os seguintes casos:

- o primeiro par é formado por parentes (José Arcádio e Úrsula); (repetição do enlace, duplo parentesco); 
- José Arcádio (filho) e o Coronel Aureliano geram seus filhos na mesma mulher, Pilar Ternera (repetição da mulher);

- Aureliano II e José Arcádio II compartilham Petra Cotes (repetição da mulher);

- repetição geral dos nomes;

- Amaranta Úrsula e Aureliano repetem o esquema de parentesco (sobrinho - tia) da relação erótica entre Amaranta e Aureliano José.

O jogo que se dá entre todos os Buendía é como um enfrentamento de espelhos: repetem-se os parentescos, as situações, os nomes, as qualidades da personalidade:

- Vai se chamar José Arcádio - disse [Aureliano Segundo].

Fernanda del Carpio, a formosa mulher com quem havia se casado no ano anterior, concordou. Já Úrsula não conseguiu ocultar um vago sentimento de aflição. Na longa história da família, a tenaz repetição dos nomes tinha permitido que ela chegasse a conclusões que lhe pareciam definitivas. Enquanto os Aurelianos eram retraídos, mas de mentalidade lúcida, os José Arcádio eram impulsivos e empreendedores, mas estavam marcados por um destino trágico. [...] (GARCÍA MÁRQUEZ, 2014, p. 220).

A própria estruturação do livro Cem anos de solidão aponta para um jogo especular, conforme acertadamente postula a ensaísta e crítica literária argentina Josefina Ludmer (1989, p. 14) ao afirmar que a referida obra compõe-se de duas metades,

uma diante da outra; o livro se fecha e se dobra sobre si mesmo; as linhas da segunda parte se correspondem e se sobrepõem às da primeira. Sobre essa ideia do livro como um espelho está construída a narração de Cem anos. Tem vinte capítulos, não numerados; os dez primeiros contam uma história, os dez últimos tornam a contá-la invertida: há dois pares de pais casados entre si, duas tias que têm a mesma idade do sobrinho varão; há, de cada acontecimento, duas inscrições: a narração está escrita duas vezes e em forma de espelho. Essa ideia do livro como espelho [...] nos remete a uma precisão: o livro chamado Cem anos de solidão é um espelho, [...] sua história se autoreflete, se duplica sobre si mesma [...].

As repetições dos nomes dos personagens - tanto femininos quanto masculinos, as situações duplicadas - as amantes dos Aurelianos e Josés Arcádios, os mortos que retornam (Prudencio Aguilar, Melquíades, José Arcádio Buendía (o patriarca), o nascimento de um ser humano com rabo de porco - no início e no final da narrativa - confirmam o jogo especular que se estabelece dentro da obra, o qual atesta que o tempo é cíclico e todas as situações vida/morte/guerra/incestos podem repetir-se ad infinitum. 
No tempo mítico (primeiro período), os Buendía nomeiam o mundo, isto é, mediante um recurso tipicamente poético, criam o mundo que os rodeia; a geografia é como um espaço fantástico:

José Arcádio Buendía ignorava por completo a geografia da região. Sabia que para os lados do oriente estava a serra impenetrável, e do outro lado da serra, a antiga cidade de Riohacha, onde em épocas passadas - segundo havia contado a ele o primeiro Aureliano Buendía, seu avô - sir Francis Drake se dava ao esporte de caçar jacarés a tiros de canhão, que depois mandava remendar e rechear de palha e despachava para a rainha Elizabeth. [...] Ao sul estavam as lagoas cobertas por uma eterna nata vegetal e o vasto universo do pântano grande, que de acordo com o depoimento dos ciganos carecia de limites. Esse pantanal se confundia ao ocidente com uma extensão aquática sem horizontes, onde havia cetáceos de pele delicada com cabeça e torço de mulher, que faziam os navegantes se perderem com feitiço de suas tetas descomunais. Os ciganos navegavam seis meses por essa rota antes de alcançar o cinturão de terra firme por onde passavam as mulas do correio. [...] (GARCÍA MÁRQUEZ, 2014, p. 52).

$\mathrm{Na}$ passagem transcrita, destaca-se a utilização de formas adjetivas que indicam indefinição de limites e de contornos. Além disso, aparece o elemento mítico na forma das supostas sereias. A mentalidade de José Arcádio é mítica, ele crê nas lendas de seu povo e dos ciganos; acolhe qualquer referência sempre que seja fantástica. Apesar de seu espírito 'científico' (que o impulsiona a experimentar maquinários, laboratórios, instrumentos) sempre está atento à percepção do extraordinário: transforma sua ciência em mito.

Depois do descobrimento da geografia, segue a relação com os objetos que povoam o mundo. A Macondo chega a peste da insônia: todos os habitantes passam as noites acordados "e organizou-se a vida e o trabalho retomou seu ritmo e ninguém tornou a se preocupar com o inútil costume de dormir" (GARCÍA MÁRQUEZ, 2014, p. 88).

José Arcádio toma consciência dos males que esse flagelo pode acarretar, mas é Aureliano quem concebe a solução para combater as fraquezas que a insônia produz na memória dos habitantes de Macondo:

Foi Aureliano quem concebeu a fórmula que haveria de defendê-los durante vários meses das evasões da memória. Descobriu-a por acaso. [...] Aureliano escreveu o nome num papel que grudou com goma arábica na base da bigorninha: bigorna. Assim, teve certeza de não esquecê-lo no futuro. [...] poucos dias depois descobriu que tinha dificuldade para se lembrar de quase todas as coisas do laboratório. Então marcou-as com os respectivos nomes, de maneira que bastava ler a inscrição para identificá-las. Quando seu pai falou de sua preocupação por ter esquecido até os fatos mais impressionantes de sua infância, Aureliano explicou seu método, e José Arcádio Buendía colocou-o 
em prática na casa inteira e mais tarde o impôs em toda a aldeia. [...] (GARCÍA MÁRQUEZ, 2014, p. 88-89).

Dessa maneira, José Arcádio aproveita a ideia do irmão e nomeia os objetos domésticos, os animais e as plantas:

[...] Pouco a pouco, estudando as infinitas possibilidades do esquecimento, percebeu que podia chegar o dia em que as coisas seriam reconhecidas por suas inscrições, mas ninguém se lembraria de sua utilidade. Então foi mais explícito. O letreiro que pendurou no cachaço da vaca era uma mostra exemplar da forma pela qual os habitantes de Macondo estavam dispostos a lutar contra o esquecimento: Esta é a vaca, e deve ser ordenhada todas as manhãs para que produza leite, e o leite deve ser fervido para ser misturado com o café e fazer café com leite. E assim continuaram vivendo numa realidade escorregadia, momentaneamente capturada pelas palavras, mas que fugiria sem remédio quando fosse esquecido o valor da letra escrita. (GARCÍA MÁRQUEZ, 2014, p. 89).

A partir desse episódio, Macondo pode construir livremente o seu passado, já que não seu futuro. A recuperação da memória e do sonho - graças a Melquíades, que intervém sempre como um "deux ex-machina”, provendo uma solução que já não era esperada -, indica praticamente a finalização do tempo mítico e o começo das eras bélicas.

Essa segunda sequência está dominada pela figura do Coronel Aureliano Buendía. Macondo começa a ser parte do mundo e da história, mas a irrefreável desmesura dos Buendía insere um grau de loucura no contexto histórico. Aureliano Buendía promove várias revoluções e acaba derrotado em todas; sua atitude é uma hipérbole do guerreiro, obscurecido pelo poder e pela paixão política. A história completa da vida de Aureliano está magnificamente narrada por García Márquez, num tom apropriado ao tema da guerra, mas acrescentando a exageração características e também o humor:

O coronel Aureliano Buendía promoveu trinta e duas rebeliões armadas e perdeu todas. Teve dezessete filhos varões de dezessete mulheres diferentes, que foram exterminados um atrás do outro numa mesma noite, antes que o mais velho fizesse trinta e cinco anos. Escapou de catorze atentados, setenta e três emboscadas e de um pelotão de fuzilamento. Sobreviveu a uma dose de estricnina no café que teria sido suficiente para matar um cavalo. [...] Declinou da pensão vitalícia que lhe ofereceram depois da guerra e até a velhice viveu dos peixinhos de ouro que fabricava em sua oficina de Macondo. Embora tenha lutado sempre à frente de seus homens, o único ferimento que sofreu foi feito por ele mesmo depois de assinar a capitulação de Neerlândia, que pôs fim a quase vinte anos de guerras civis. Disparou um tiro de pistola no próprio peito e o projétil saiu pelas costas sem atingir nenhum órgão vital. A única coisa que ficou disso tudo foi uma rua com o seu nome em Macondo. [...] (GARCÍA MÁRQUEZ, 2014, p. 144). 
A forte figura do coronel, arrogante, exagerado e taciturno, fica reduzida a um nome. Nisso se sintetiza a inutilidade e o completo absurdo das guerras civis das quais participou Aureliano. A referências aos peixinhos de ouro que ele fabricava no antigo escritório da casa paterna permite-nos enlaçar este segundo período com o terceiro, aquele que chamamos de cíclico. Nele, os primeiros personagens envelhecem e morrem, submersos nas recordações e no passado. O tempo repete-se, aparecem objetos recorrentes, todos eles de caráter simbólico: os peixinhos de ouro de Aureliano; as figurinhas de animais feitas de açúcar por Úrsula; a mortalha que Amaranta borda interminavelmente. Esses objetos representam um resgate do tempo, ou seja, adiam o tempo da morte de cada um dos personagens.

Amaranta morre quando termina seu trabalho de costurar a mortalha: cumpriu seu ciclo, tecendo e destecendo o tempo em suas mãos. A morte aparece personificada no romance e encontra-se com Amaranta:

[...] a morte deparou-lhe o privilégio de se anunciar com vários anos de antecipação. Viu-a num meio-dia ardente, costurando com ela na varanda das begônias, pouco depois que Meme foi para o colégio. Reconheceu-a no ato e não havia nada de pavoroso na morte, porque era uma mulher vestida de azul e com os cabelos longos, de aspecto um pouco antiquado, e um tanto parecida com a Pilar Ternera da época em que a ajudava nos ofícios de cozinha. Várias vezes Fernanda estava presente e não a viu, apesar de ela ser tão real, tão humana, que em certa ocasião pediu a Amaranta o favor de passar a linha numa agulha. A morte não disse quando ela ia morrer, nem se sua hora estava marcada antes que a de Rebeca, mas mandou que começasse a tecer sua própria mortalha no próximo dia seis de abril. Autorizou que fosse tão complicada e primorosa como ela quisesse, [...] e advertiu que haveria de morrer sem dor, nem medo, nem amargura, no anoitecer do dia em que a terminasse. [...] (GARCÍA MÁRQUEZ, 2014, p. 267).

Novamente, um feito insólito amalgama-se ao mundo cotidiano e corriqueiro dos personagens: a morte vem visitar Amaranta e ambas costuram lado a lado e dialogam, sem qualquer assombro. Desse modo, Amaranta, como uma Penélope latino-americana, vai tecendo e destecendo a sua mortalha, até finalmente concluí-la e assim materializam-se as palavras ditas pela "mulher vestida de azul" e de cabelos compridos.

No terceiro ciclo, chega a Macondo a invasão do mundo exterior, através da companhia bananeira. O primeiro indício é a chegada do trem, nunca visto antes pelos habitantes de Macondo:

[...] No começo do outro inverno, porém, uma mulher que lavava roupa no rio na hora de mais calor atravessou a rua principal dando gritos em um alarmante estado de comoção. 
- Vem vindo aí - conseguiu explicar - uma coisa espantosa, feito um fogão arrastando uma cidade.

[...] Mas quando todos se restabeleceram do desconcerto dos apitos uivantes e dos gigantescos suspiros ofegantes, os habitantes saíram às ruas e viram Aureliano Triste na locomotiva, acenando com a mão, e viram, enfeitiçados, o trem adornado de flores que chegava com oito meses de atraso. O inocente trem amarelo que tantas incertezas e evidências, e tantas alegrias e desventuras, tantas mudanças, calamidades e nostalgias haveria de levar a Macondo. (GARCÍA MÁRQUEZ, 2014, p. 260).

Merece reparo o emprego da cor amarela, que além de ser o atributo do trem que chega a Macondo, aparece relacionada a outras situações e personagens:

\begin{abstract}
"Minúsculas flores amarelas." Esse conjunto [...] se refere à dentadura postiça que Melquíades abandonou um dia no copo e não tornou a usar. Nesse copo "haviam colocado umas plantinhas aquáticas de minúsculas flores amarelas". Quando morre José Arcádio Buendía, caiu uma "chuvinha de minúsculas flores amarelas" que cobrem todo o povoado [...].

Por outro lado, Mauricio Babilônia está permanentemente cercado de borboletas amarelas [...] que o acompanham até a morte. Melquíades, José Arcádio Buendía e Mauricio Babilônia encontram-se assim ligados por meio de certa cor, de um elemento pequeno que toma a forma de aquático (Melquíades), de aéreo (Babilônia) e de intermediário entre aéreo e terrestre (José Arcádio Buendía). Os três pais: o de toda estirpe (José Arcádio Buendía), o do último Aureliano, que fecha a estirpe (Mauricio Babilônia) e o pai dos manuscritos, do texto (Melquíades) se identificam através do amarelo e de um pequeno objeto natural que conota sol, vida, ação de gerar. (LUDMER, 1989, p. 63-64, grifos da autora).
\end{abstract}

Nesse sentido, a cor que adjetiva o trem deve ser relacionada com o progresso, com a invasão do civilizado no mundo fechado e retrógrado que é Macondo, pois com o trem penetram em Macondo as novidades daquilo que chamamos de vida moderna, que também introduz as “incertezas", "desventuras", "mudanças", “calamidades" e "saudades". Enfim, uma série de transformações que afetariam Macondo para sempre.

Depois do trem chega o sorridente Mr. Herbert, que estuda o fruto da banana de forma tão escrupulosa que toda a família Buendía espera alguma revelação ao final de tão conscienciosa investigação. No entanto, o que faz Mr. Herbert é sinalizar para que se inicie a exploração da banana em Macondo. O povo assiste assombrado às mudanças na geografia local:

[...] Ninguém ainda sabia o que é que procuravam, ou se na verdade não passavam de filantropos, e já haviam ocasionado um transtorno colossal, muito mais perturbador que o dos antigos ciganos, mas menos transitório e compreensível. Dotados de recursos que em outros tempos estavam reservados à Providência Divina, modificaram o regime das chuvas, apressaram o ciclo das colheitas, e tiraram o rio de onde sempre esteve e o puseram com suas pedras brancas e suas correntes geladas no outro extremo 
do povoado, atrás do cemitério. Foi nessa ocasião que construíram uma fortaleza de concreto armado sobre a desbotada tumba de José Arcádio, para que o cheiro de pólvora do cadáver não contaminasse as águas. [...] (GARCÍA MÁRQUEZ, 2014, p. 264-265).

Depois de levar a Macondo um momento de esplendor econômico, a companhia bananeira arrasa com três mil homens, executando uma matança sem precedentes no povoado. É o fim da febre da banana. A sinistra exploração que a companhia bananeira cumpre até o fim liga o romance de García Márquez com a melhor tradição da narrativa latino-americana, no campo realista testemunhal. Entretanto, os episódios carecem de tom panfletário ou discursivodoutrinário, como ocorre em outras obras do "ciclo da terra". A tragédia da exploração e a crueldade da matança intercalam-se no texto quase como uma visão fantástica, pois o desejo de sobreviver obriga as pessoas a guardar as recordações de tais fatos somente em sua memória, sem nunca falar desse assunto.

O quarto e último período é o da destruição e morte de Macondo, junto com os descendentes finais da estirpe dos Buendía. Ali, ao morrer Amaranta e o filho monstruoso que gerou com Aureliano, o ciclo remonta-se até a origem da família, pois o tão temido filho com rabo de porco acaba de nascer e arrastará consigo o povoado, que se transforma em um redemoinho. A solidão essencial - intrínseca dos Buendía - recobra sua razão de ser e sua justificativa, que tantos anos de adiamento tinham escondido:

[...] Macondo já era um pavoroso redemoinho de poeira e escombros centrifugados pela cólera do furacão bíblico quando Aureliano pulou onze páginas para não perder tempo em fatos demasiado conhecidos e começou a decifrar o instante que estava vivendo, decifrando conforme vivia esse instante, profetizando a si mesmo no ato de decifrar a última página dos pergaminhos, como se estivesse se vendo num espelho falado. Então deu outro salto para se antecipar às predições e averiguar a data e as circunstâncias de sua morte. Porém, antes de chegar ao verso final já havia compreendido que não sairia jamais daquele quarto, pois estava previsto que a cidade dos espelhos (ou das miragens) seria arrasada pelo vento e desterrada da memória dos homens no instante em que Aureliano Babilônia acabasse de decifrar os pergaminhos, e que tudo que estava escrito neles era irrepetível desde sempre e para sempre, porque as estirpes condenadas a cem anos de solidão não tinham uma segunda chance sobre a terra. (GARCÍA MÁRQUEZ, 2014, p. 447).

Ao final, triunfa a imaginação e os Buendía tropeçam num poço sem fundo: o poço de sua própria e irremediável solidão. $\mathrm{O}$ ato de decifrar os pergaminhos de Melquíades, frequentemente adiado nas gerações anteriores, consuma-se no penúltimo Buendía, filho de Meme e Mauricio Babilônia, um filho bastardo, que a avó, Fernanda, encarregou-se de criar e 
ocultar a sua origem. A descoberta de seu parentesco com a mulher que ama, Amaranta Úrsula, sua tia, a consumação do incesto, a confirmação da profecia anunciada no início do romance o nascimento de uma criança com rabo de porco e a decodificação dos manuscritos do cigano Melquíades, acarretam o fim de Macondo e da estirpe dos Buendía.

A intercalação de eventos extraordinários na realidade cotidiana dos personagens por meio da técnica do realismo mágico, o uso de temporalidades cíclicas pela repetição dos nomes dos personagens, das situações e a intertextualidade com a Bíblia e o resgate da história bélica das nações latino-americanas fazem de Cem anos de solidão uma obra monumental, um manancial inesgotável para estudos e questionamentos e permite ao leitor pensar/repensar a sua própria situação na América Latina, a exploração de nações de estrangeiras, o jogo de interesses, a grandeza e a mesquinharia do ser humano que, invariavelmente, também estará condenado à solidão, ao aniquilamento, ao pó, destino do qual ninguém pode fugir.

\section{REFERÊNCIAS}

GARCÍA MÁRQUEZ, Gabriel. Cem anos de solidão. 82. ed. Tradução de Eric Nepomuceno. Rio de Janeiro: Record, 2014.

KAAL, Friedl. Oposición y concordancia entre lo real maravilloso y el realismo mágico. Thesis (Master of Arts). Department of Spanish - Language and Literature. McGill University, 1975.

LODGE, David. A arte da ficção. Tradução de Guilherme da Silva Braga. Porto Alegre: L\&PM, 2011.

LUDMER, Josefina. Cem anos de solidão: uma interpretação. 1. ed. Tradução de Antonio de Padua Danesi. São Paulo: Martins Fontes, 1989.

MOISÉS, Massaud. Dicionário de termos literários. 12. ed. ver. e ampl. São Paulo: Cultrix, 2004.

OVIEDO PÉREZ DE TUDELA, Rocío. Huellas de vanguardia: realismo mágico/literatura fantástica. Esbozo de una relación. Anales de Literatura Hispanoamericana, 1999, 28: 323341.

RUIZ SERRANO, Cristina. El realismo mágico de las últimas décadas en hispanoamérica e Rusia. ¿Hibridez o desaparición? p. 175-194. Disponível em: <https://gupea.ub.gu.se/bitstream/2077/10428/1/gupea_2077_10428_1.pdf> Aceso em: 23 jun. 2018. 